\title{
Plant-Derived Bioactive Peptides: A Treatment to Cure Diabetes
}

\author{
Shital P. Patil ${ }^{1}$ Ashutosh Goswami ${ }^{1} \cdot$ Kiran Kalia $^{2} \cdot$ Abhijeet S. Kate $^{1} \mathbb{0}$
}

Accepted: 18 July 2019 / Published online: 22 July 2019

(c) Springer Nature B.V. 2019

\begin{abstract}
Recent advances in analytical techniques have opened new opportunities for plant-based drug discovery in the field of peptide and proteins. Enzymatic hydrolysis of plant parent proteins forms bioactive peptides which are explored in the treatment of various diseases. In this review, we will discuss the identified plant-based bioactive proteins and peptides and the in vitro, in vivo results for the treatment of diabetes. Extraction, isolation, characterization and commercial utilization of plant proteins is a challenge for the pharmaceutical industry as plants contain several interfering secondary metabolites. The market of peptide drugs for the treatment of diabetes is growing at a fast rate. Plant-based bioactive peptides might open up new opportunities to discover economic lead for the management of various diseases.
\end{abstract}

\section{Graphic Abstract}

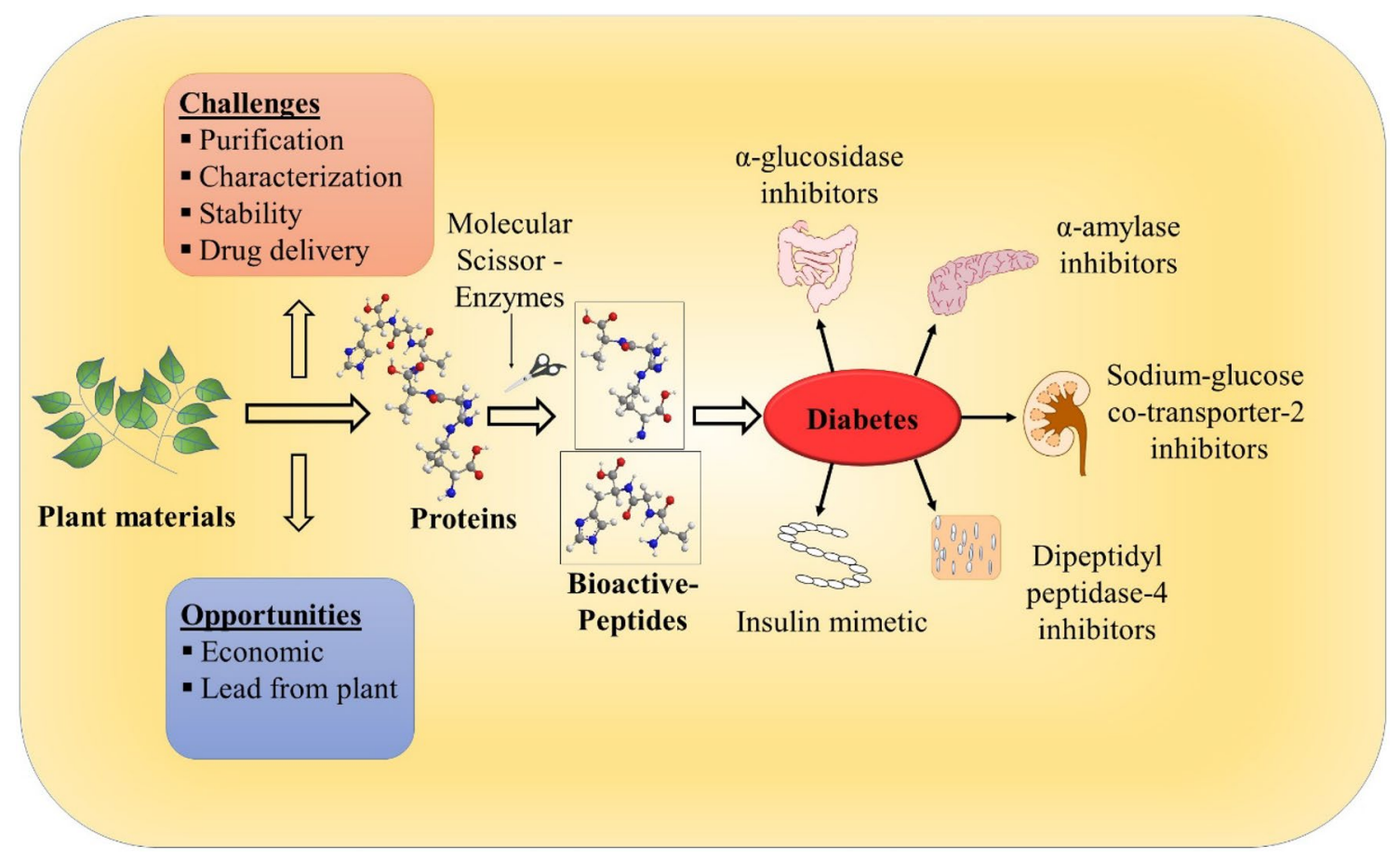

Keywords Plants $\cdot$ Seeds $\cdot$ Proteins $\cdot$ Bioactive peptides $\cdot$ Antidiabetic activity

Abhijeet S. Kate

kate.abhi.s@gmail.com

Extended author information available on the last page of the article 


\section{Introduction}

Biomolecules play an important role in any ligand-target interaction and their recognition in any biological system starts the cascade of signalling steps, which is an important part of the normal body function. Nucleic acids, carbohydrates, and lipids are the important ligands that bind and cause conformational changes in targets (receptors) but the messengers that release after binding and conformation changes are peptides. Any defect in these signal transduction processes cause diseases (Otvos and Wade 2014; Gautam 1999). Proteins, under the influence of proteolytic enzymes get fragmented at particular catalytic sites to form bioactive peptides. Bioactive peptides are made up of 2-20 amino acids and lack protein-protein interaction because of their small size. They have properties like tissue affinity, specificity, and efficiency (Moller et al. 2008). The structure and the overall charge and hydrophobicity/hydrophilicity of the any bioactive peptide depends on the nature of amino acids, their sequences in the peptide backbone along with the $\mathrm{N}$ and $\mathrm{C}$ terminals. The relation between structure and biological activity of the bioactive peptides are yet not confirmed but the structure is an important arbitrator for their activity ( $\mathrm{Li}$ and $\mathrm{Yu}$ 2015). Bioactive and nutraceutical peptides have a positive effect in the regulation of the health of an individual (Kitts and Weiler 2003). They boost the quality of human health by preventing various ailments and by improving medical conditions related to lifestyle, metabolism, and immunity (Vitetta et al. 2005).

Peptide and protein drugs are available from the different sources for therapeutic uses, but as with many drugs, they have several advantages and disadvantages of their own. Peptide drugs are effective and specific to their biological target but devoided of some of the essential qualities of a drug to withstand in the current market of therapeutics. Proteins have a large chemical structure which makes their synthesis complex, tedious and expensive, the further low oral bioavailability of proteins limit their oral delivery hence they are administered through parenteral route (Uhlig et al. 2014). The worldwide peptide therapeutics market size valued at USD 22,071.5 million in 2017 and assumes to grow at CAGR of $9.1 \%$ over the period 2018 to 2026. (2016). Insulin is the first therapeutic peptide which has been used widely and shares good peptide market. It was first isolated by Frederick Banting and Charles Best from pancreatic islet extracts, further, J.B. Collip developed the method for extraction and purification of insulin from other animal sources (Quianzon and Cheikh 2012). Eli Lilly began producing insulin from the animal pancreas, later on, biosynthetic insulin was introduced in 1983 with the name Humulin. Novo Nordisk,
Sanofi, and Eli Lilly together share 88.7 percent of the global insulin market. Lantus (basal insulin) is a product of Sanofi accounts for approximately $22.29 \%$ of the total sales of top 10 antidiabetic drug brands, in 2016 sale of Lantus was USD 6.057 billion (Dezzani 2017). Small molecules and peptide-based drug candidate belongs to the category of New Chemical Entities (NCEs) according to the Food and Drug Administration, on the other hand, proteins used for the treatment of various diseases are classified under New Biological Entities (NBEs).

In recent years, therapeutic peptides are approved for the mitigation of various ailments mainly tumors, immunological disorders, blood disorders and metabolic disorders such as diabetes, obesity (Fig. 1) (Loganathan 2016). The peptide drug, liraglutide (Victoza) is a glucagon-like peptide-1 receptor (GLP-1R) agonist and used for the treatment of T2DM has gained popularity as a top-selling drugs in recent past, which is marketed by Novo Nordisk (Lund et al. 2014). Glatiramer acetate (Copaxone), developed by Teva is an immunomodulator and used to treat multiple sclerosis (Duda et al. 2000). Leuprolide (Lupron), developed by Abbott is useful for the treatment of cancer and estrogendependent conditions that respond to hormone therapy (Brito et al. 2004). Goserelin (Zoladex) from Astra Zeneca is a gonadotropin-releasing hormone agonist ( $\mathrm{GnRH}$ agonist) that suppresses the release of different sex hormones and is useful in the treatment of breast and prostate cancer (Magon 2011). Other innovator companies include Amgen, Eli Lilly, Roche, and Pfizer have peptide and protein-based drugs in different developmental stages will reach the market soon for the treatment of various complicated diseases (Loganathan 2016).

Till date, plant secondary metabolites, mainly small molecules are the established source of new drugs to treat various diseases (Verpoorte 1998), however, advancement in analytical technique, sophisticated purification methodology and in vitro assay system pointed out the researchers

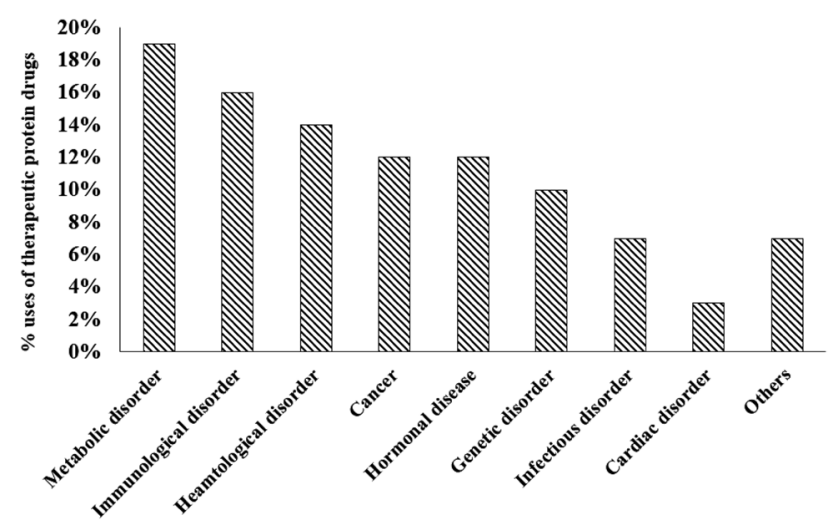

Fig. 1 Uses of therapeutic peptides and proteins in various disease conditions (Loganathan 2016) 
to look beyond the small molecules. Identification of plant primary metabolites including proteins and peptides for the management of diseases have opened up a new horizon in the development of plant-based peptides as a drug candidate (Otvos 2008). This review summarizes various plant-based peptides reported for the treatment of diabetes, challenges with the development of peptide-based drugs and the future prospect of peptides as a drug.

\section{Diabetes Mellitus}

Diabetes is a metabolic disorder and can hit anyone at different stages of life. Though it is considered as one of the top health killers, its treatment is a huge challenge. Diabetes can be characterized with symptoms of prolonged hyperglycemia, glucose intolerance, disturbance in the regulatory systems for storage and utilization of metabolic energy, including catabolism and anabolism of carbohydrate, lipids, and proteins in a diabetic individual due to lack of insulin production and impaired insulin receptor functioning or both (Piero 2015; Votey and Peters 2005). Based on the causes and clinical survey, diabetes mellitus is categorized into four types as mentioned in Table 1 (Deepthi et al. 2017).

Ordinarily, the people below 18 age suffer from the type 1 diabetes, whereas type 2 diabetes mainly occurs in adult and old age group. According to the World Health Organisation, approximately $10 \%$ of all diabetes cases are type 1 , and the remaining $90 \%$ cases of diabetes worldwide are of type 2 (Baynes 2015). Diabetes is ruining the life of peoples worldwide. Population suffering from diabetes is increasing and the imminence is expected to rise even more because of the current lifestyle issues. Till the year 2017, 422 million people were affected by type 2 diabetes and the number is expected to increase up to 642 million people worldwide by 2040 (Fig. 2). The data indicates that approximately $50 \%$ of diabetic patients will increase in the next two decades. The threat is every $6 \mathrm{~s}$ a person dies with diabetes (Roglic 2016).

From the statistics, it is clear that the population suffering from type 2 diabetes is increasing and it requires more promising therapies. Still, no promising drug is available which

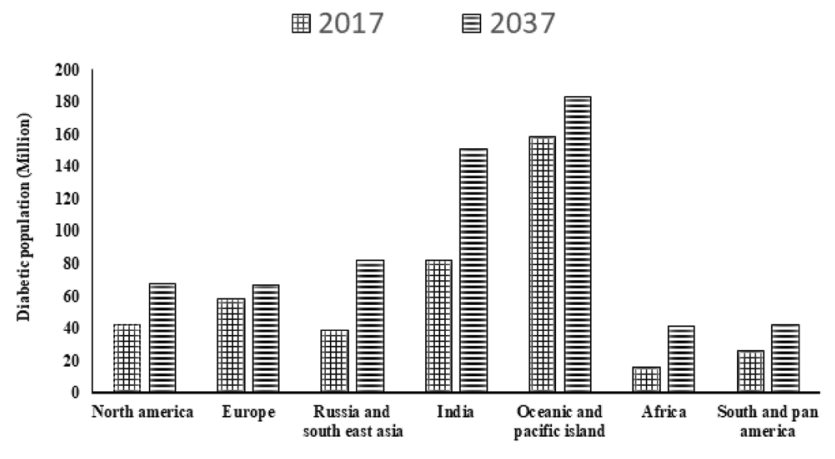

Fig. 2 Epidemiology of diabetes country wise (2017a)

has the ability to completely cure type 2 diabetes. Generally, to treat type 2 diabetes, oral hypoglycemic agents are used. The first line treatment is metformin, which is assisted with other hypoglycemic agents from different categories like thiazolidinediones, alpha-glucosidase inhibitors, sulphonylurea, dipeptidyl peptidase-IV (DPP-IV) inhibitors, sodium glucose cotransporter 2 (SGLT 2) inhibitors. The risk associated with these therapies include hypoglycemia, weight gain, tiredness, diarrhea, and anemia risk, etc. Over the period of time, these side effects lead to further complications for a visceral system like cardiovascular system and central nervous system (Nathan et al. 2009).

Peptide drugs used for the treatment of diabetes are derived from different sources, like Exendin-4 was initially isolated from the Heloderma suspectum (Gila monster) and its synthetic version had come to the market in the form of exenatide (Aramadhaka et al. 2013). Liraglutide and Semaglutide are structurally very close to GLP-1 with improved half-life and resistant to DPP-IV mediated degradation (Edmonds and Price 2013). Nowadays, these peptides are being produced in large scale by using recombinant DNA technology. The peptides which were obtained via synthesis or by using the recombinant technology are comparatively expensive than small molecules and are not affordable to most of the patients. The interest in health-promoting products from the natural origin and pharmaceutical formulations involving bioactive peptides are remarkably increasing
Table 1 Types of diabetes and their characteristics

\begin{tabular}{ll}
\hline Types & Characteristics \\
\hline Type 1 diabetes & Destruction of the beta cell, reduced insulin secretion \\
Type 2 diabetes & Normal Insulin secretion \\
& Glucose storing cells developing insulin resistance \\
Gestational diabetes & Dysfunction of an endocrine gland present in the pancreas \\
& Endogenous disease such as rubella and Cytomegalovirus \\
& Due to drugs and chemicals exposure \\
Other specific diabetes & Does not last long and develops at the time of pregnancy \\
& mostly during the end of the first trimester \\
& Post delivery, the blood sugar comes to normal \\
\hline
\end{tabular}


(Henninot et al. 2018). Numerous scientific reports have been published on bioactive peptides obtained from animal proteins. Expedition by researchers in the field of bioactive peptides is of great interest as it opens the way to find economic lead from plants for the better care of diabetic patients (Daliri et al. 2017).

\section{Plant-Derived Bioactive Peptides}

Plentiful bioactive peptides have been reported from the animal and plant sources. Most of the peptides that had bioactivity are being derived from animal products such as milk, eggs, meat, and fish. Plant peptides are still under exploration and few bioactive peptides are reported from soy, wheat, etc (Hartmann and Meisel 2007). In animals, proteins are associated with high-fat content and lead to diseases, including high blood pressure and heart diseases if consumed in the large amount. On the other hand, plant proteins neither have associated fat nor have any side effects (Nehete et al. 2013). Previously, plant hormones were considered the only player through which cells communicate, but from the last decade as research was driven towards an understanding of plants signaling, secreted peptides, small RNAs and transcription factors emerging as a new and well-defined player in the cell to the cell communication network (Lindsey et al. 2002; Van Norman et al. 2011; Murphy et al. 2012). However, it is now clearly defined that signaling peptides of plant and animal origin are biosynthesized through the pathway that is evidently similar, although some aspects of the biosynthesis are still not identified. Peptides secreted by plants have well recognized role in preliminary processes of development like the growth of meristem, organ shedding, cell elongation, cell multiplication, cell differentiation, geotropism and protection from the invader (Ghorbani 2014). The ubiquitous presences of proteins, peptides as mediator components convey to the proposals that these messenger peptides may have emerged evolutionary in microbes and were further integrated into the complicated mediator systems of complex organisms during evolution (Roth et al. 1982). Existence of hormone-like peptides in plants including insulin-like peptide in Spinacia oleracea L. (Spinach) and Lemna gibba G-3, prolactin-like inhibitor in alfalfa, a substance with luteinizing hormone-releasing activity from leaves of Avena sativa L. (Oat) and somatostatin-like material in spinach support this assumption, it is speculated that the signaling peptides in plants existed from about 1 billion years ago (Collier et al. 1987; Fukushima et al. 1976; Leroith et al. 1985; Morley et al. 1980). Plant proteins containing essential amino acids are important in the food chain to fulfill human physiological needs. The proteins from plants are derived from leaves, seeds, and fruits, out of which seeds are considered as an economical source of proteins. As compared to vegetables and fruits, seeds (legumes and cereals) contain a higher amount of protein (Creighton 1993). Proteins in a mature seed represent $18-20 \%$ in Pisum sativum L. (Pea), Vicia faba L. (Faba) bean and till $35-45 \%$ in Lupinus albus L. (Lupin) and Glycine max L. (Soybean) (Gueguen and Cerletti 1994).

\section{Reported Antidiabetic Bioactive Peptides from Plants}

Many peptides are reported from different plants for the treatment of diabetes as shown in Tables 2 and 3 through various known targets such as

(a) Alpha-glucosidase inhibitors

(b) Alpha-amylase inhibitors

(c) Dipeptidyl peptidase-IV inhibitors

(d) Inhibitors of the glucose transporter system

(e) Insulin mimetics

\section{Alpha-glucosidase Inhibitor}

Alpha-glucosidase inhibitors competitively inhibit small intestinal enzyme alpha-glucosidase, which converts nonabsorbable polysaccharides into absorbable monosaccharide, these effects together postpone and minimize the rise in postprandial plasma glucose level. Inhibitors of this enzyme decrease the glucose toxicity (improves insulin sensitivity), decreases stress on beta cells (decreases post-meal hyperglycemia), increases glucagon like peptide-1 (GLP-1) production hence increases insulin secretion (Scheen 2003; Mooradian and Thurman 1999). In general, normalization of postprandial hyperglycemia is difficult as compared to fasting hyperglycemia, inhibitors act specifically on the postprandial part of $24 \mathrm{~h}$ blood glucose curve and causes a reduction in diabetes-associated hyperglycemia which is responsible for macrovascular complication in patients (Mooradian and Thurman 1999; Ceriello et al. 2004). Glycaemic control is achieved with these agents reduces glucotoxicity which increases insulin secretion from the beta cell (Scheen 2003; Salvatore and Giugliano 1996).

All marketed alpha-glucosidase inhibitors are from natural origin, however, none of them belongs to peptide class. Few research groups have reported peptides from plants having alpha-glucosidase inhibitory activity. Peptides obtained from Cannabis sativa L. (Hemp) seeds contains hydrophobic amino acids (Pro and Leu), essential amino acids and branched chain amino acids in their structure and have reported to have enzyme inhibitory activity for this target (Ren et al. 2016). Oat seed proteins hydrolysate obtained by protease (alcalase) digestion gives bioactive peptides which inhibits this enzyme. In vivo study also revealed 
Table 2 Reported peptides sequences from plants for antidiabetic activity

\begin{tabular}{|c|c|c|c|c|c|}
\hline Sr. no & Plants & Sequences & Target & Study & References \\
\hline 1 & $\begin{array}{l}\text { Amaranthus hypochon- } \\
\text { driacus L. }\end{array}$ & $\begin{array}{l}\text { PPPP, GP, PP, MP, VA, } \\
\text { MA, KA, LA, FA, AP, } \\
\text { FP, } \\
\text { PA, LP, VP, LL, VV, HA, } \\
\text { IPA, IPI }\end{array}$ & DPP-IV inhibition & In vitro & $\begin{array}{l}\text { Velarde-Salcedo et al. } \\
\text { (2013) }\end{array}$ \\
\hline 2 & $\begin{array}{l}\text { Cannabis sativa } \mathrm{L} \text {. } \\
\text { (Hemp). }\end{array}$ & LR and PLMLP & $\begin{array}{l}\text { Alpha-glucosidase inhibi- } \\
\text { tory }\end{array}$ & In vitro & Ren et al. (2016) \\
\hline 3 & $\begin{array}{l}\text { Phaseolus vulgaris L. } \\
\text { (Pinto) }\end{array}$ & $\begin{array}{l}\text { PPHMLP, PPMHLP, } \\
\text { PLPWGAGF, GNAAC- } \\
\text { CGLPLLP, PPHMGGP, } \\
\text { PLPPHALL, PAPFP- } \\
\text { SPHTP }\end{array}$ & alpha-amylase inhibitory & In vitro & Ngoh and Gan (2016) \\
\hline 4 & $\begin{array}{l}\text { Oryza sativa } \mathrm{L} . \\
\text { (Rice bran) }\end{array}$ & LP, IP, MP, VP & DPP-IV inhibition & In vitro & Hatanaka et al. $(2012,2015)$ \\
\hline 5 & $\begin{array}{l}\text { Glycine max } \mathrm{L} . \\
\text { (Soy) and } \\
\text { Lupinus albus } \mathrm{L} . \\
\text { (Lupin) }\end{array}$ & $\begin{array}{l}\text { IAVPTGVA, YVVNP- } \\
\text { DNDEN, YVVNPDN- } \\
\text { NEN, LTFPGSAED, } \\
\text { LILPKHSDAD, } \\
\text { GQEQSHQDEGVIVR }\end{array}$ & DPP-IV inhibition & In vitro & Lammi et al. (2016) \\
\hline 6 & $\begin{array}{l}\text { Phaseolus vulgaris L. } \\
\text { (Common bean) }\end{array}$ & $\begin{array}{l}\text { AKSPLF, ATNPLF, } \\
\text { FEELN, and LSVSVL }\end{array}$ & $\begin{array}{l}\text { (GLUT2) inhibitor, } \\
\text { (SGLT1) inhibitor }\end{array}$ & In vitro and in vivo & Mojica et al. (2017a) \\
\hline 7 & $\begin{array}{l}\text { Avena sativa } \mathrm{L} . \\
\text { (Oat) }\end{array}$ & $\begin{array}{l}\text { FLQPNLDEH, } \\
\text { DLELQNNVFPH, and } \\
\text { TPNAGVSGAAAGA } \\
\text { GAGGKH }\end{array}$ & Alpha-glucosidase activity & In vitro and in vivo & Zhang et al. (2015) \\
\hline 8 & Momordica charantia $\mathrm{L}$. & GHPYYSIKKS & Hypoglycemic & In vivo & Yuan et al. (2008) \\
\hline 9 & $\begin{array}{l}\text { Phaseolus vulgaris L. } \\
\text { (Common bean) }\end{array}$ & $\begin{array}{l}\text { LLSL, QQEG, and } \\
\text { NEGEAH }\end{array}$ & $\begin{array}{l}\text { alpha-glucosidase inhibi- } \\
\text { tion, amylase inhibition }\end{array}$ & In vitro & $\begin{array}{l}\text { Oseguera-Toledo et al. } \\
\text { (2015) }\end{array}$ \\
\hline 10 & $\begin{array}{l}\text { Cuminum cyminum L. } \\
\text { (Cumin) }\end{array}$ & $\begin{array}{l}\text { FFRSKLLSDGAAAAK- } \\
\text { GALLPQYW, } \\
\text { RCMAFLLSD- } \\
\text { GAAAAQQLLPQYW, } \\
\text { and DPAQPNYPWTAV- } \\
\text { LVFRH }\end{array}$ & alpha -amylase inhibition & In vitro & Siow and Gan (2016) \\
\hline 11. & $\begin{array}{l}\text { Phaseolus vulgaris L. } \\
\text { (Common bean) }\end{array}$ & TTGGKGGK & $\begin{array}{l}\text { alpha-glucosidase inhibi- } \\
\text { tion }\end{array}$ & In vitro and In silico & Mojica and de Mejía (2016) \\
\hline 12 & $\begin{array}{l}\text { Chenopodium quinoa } \\
\text { Wild. }\end{array}$ & $\begin{array}{l}\text { IQAEGGLT, DKDYPK, } \\
\text { GEHGSDGNV }\end{array}$ & $\begin{array}{l}\text { Alpha-glucosidase inhibi- } \\
\text { tion, } \\
\text { alpha -amylase inhibition, } \\
\text { DPP- IV inhibitor }\end{array}$ & In vitro & Vilcacundo et al. (2017) \\
\hline 13. & $\begin{array}{l}\text { Morus alba } \mathrm{L} \text {. } \\
\text { (Mulberry) }\end{array}$ & WGYENAATYFWQTV & $\begin{array}{l}\text { alpha-glucosidase inhibi- } \\
\text { tion }\end{array}$ & In vitro & Jha et al. (2018) \\
\hline 14. & Glycine $\max \mathrm{L}$. & YPFVV & Hypoglycemic & In vivo & Yamada et al. (2011) \\
\hline
\end{tabular}

$G$ glycine, $A$ alanine, $L$ leucine, $M$ methionine, $F$ phenylalanine, $W$ tryptophan, $K$ lysine, $Q$ glutamine, $E$ glutamic acid, $S$ serine, $P$ proline, $V$ valine, $I$ isoleucine, $C$ cysteine, $Y$ tyrosine, $H$ histidine, $R$ arginine, $N$ asparagine, $D$ aspartic acid, $T$ threonine, $k D a$ kilo dalton

that oat peptides, at a higher dose, showed the hypoglycaemic effect on STZ-induced diabetic mice, reduces the food intake, stimulates insulin secretion, improves insulin sensitivity and elevate glycogenesis (Zhang et al. 2015). Walnut hydrolyzed peptides (WHPs) from the fruit proteins of Juglans mandshurica Maxim. (Walnut) showed anti-diabetic activity by inhibiting the enzyme. In vitro study of WHPs showed that peptides of molecular weight (3-10 kDa) inhibit alpha-glucosidase with the inhibitory rate of $(61.73 \%)$ and they remarkably raise extracellular glucose consumption in insulin-resistant HepG2 cells. Whereas, in vivo results showed that WHPs reduce $64.82 \%$ of fasting blood glucose level by increasing insulin secretion, liver glucokinase, and glycogen level by $23.71 \%, 69.54 \%$, and $76.19 \%$ respectively (Wang et al. 2018).

Vigna angularis Wild. (Adzuki bean) proteins have reported enzyme inhibitory properties in mice model KK-Ay of diabetes. The extract reduces the postprandial 


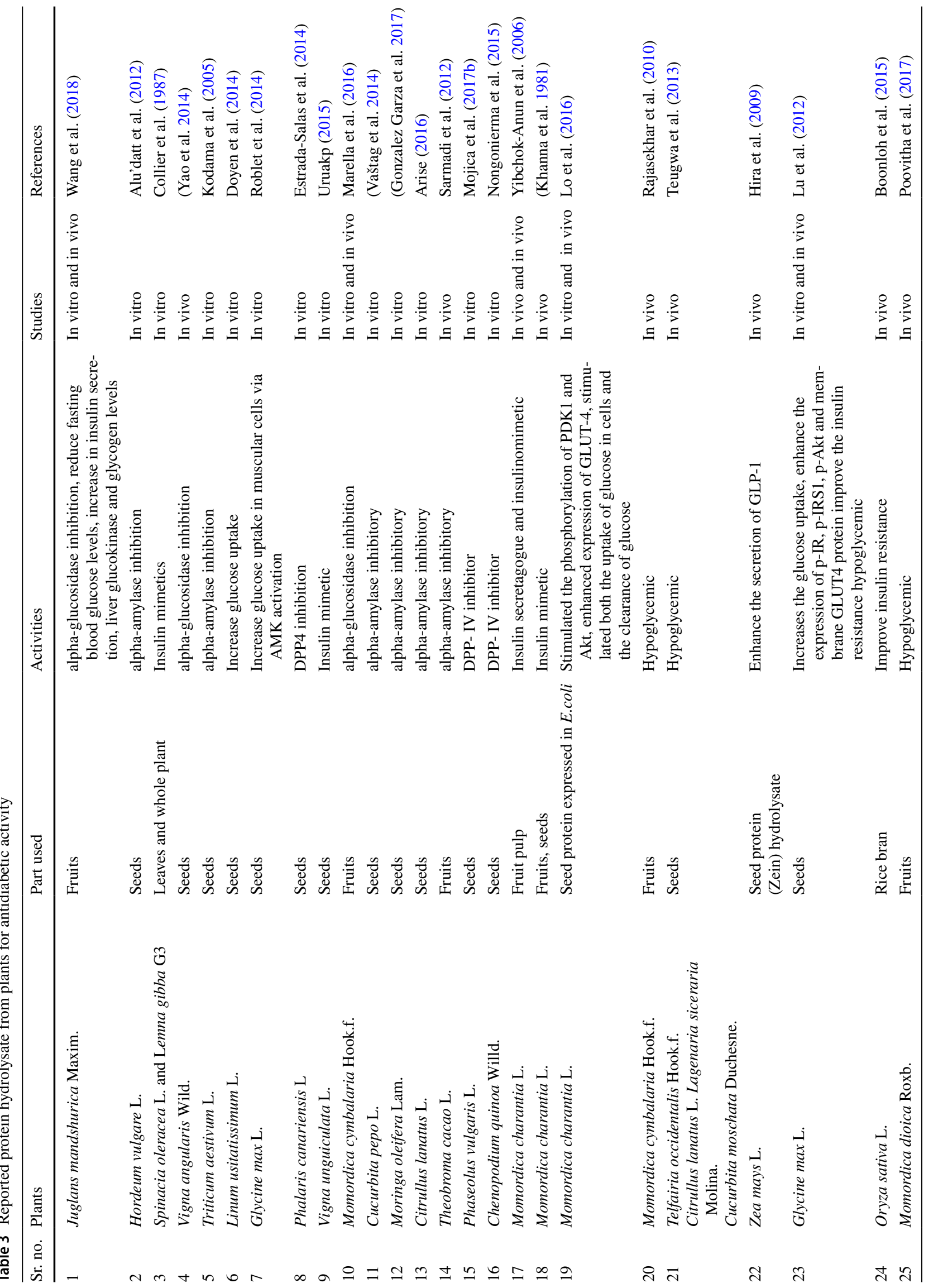


blood glucose in two sucrose challenge model i.e. normal and streptozocin-treated rats by $15.6 \%$ and $30.9 \%$ respectively. In vitro study of extruded adzuki bean proteins at $10 \mathrm{mg} / \mathrm{mL}$, concentration inhibits $60.44 \%$ of rat intestinal alpha-glucosidase (Yao et al. 2014). A peptide fraction with molecular weight $<1 \mathrm{kDa}$ obtained from a protein-rich extract of Phaseolus vulgaris L. (Pinto Durango and Negro 8025 ) common beans via hydrolysis and ultracentrifugation processes have shown $76.4 \pm 0.5 \%$ of enzyme inhibition (Oseguera-Toledo et al. 2015). Alcalase hydrolysis of proteins from Phaseolus vulgaris L. (Black bean) with enzyme to substrate ratio $(\mathrm{E} / \mathrm{S})$ ratio of $1: 20$ and incubation time for $2 \mathrm{~h}$ showed $66.1 \%$ enzyme inhibition (Mojica and de Mejía 2016). In vitro digestion of the Chenopodium quinoa Willd. (Quinoa) protein gives bioactive peptides having amino acid sequences characterized by LC-MS/MS are IQAEGGLT, DKDYPK and GEHGSDGNV showed enzyme inhibition $55.85 \%, 22.16 \%, 30.84 \%$ respectively at $250 \mu \mathrm{M}$ concentration (Vilcacundo et al. 2017). Oligopeptide having a molecular weight between 0.5 and $3 \mathrm{kDa}$ from the leaves of the Morus alba L. (mulberry) showed enzyme inhibition with $\mathrm{IC}_{50}$ value $12.56 \mu \mathrm{g} / \mathrm{ml}$ (Jha et al. 2018). Protein from Momordica cymbalaria Hook. f. showed in vitro enzyme inhibition which decreases glucose production, improve carbohydrate metabolism in animal studies (Marella et al. 2016).

\section{Alpha-amylase Inhibitors}

Amylase (alpha-1,4-glucan-4-glucanohydrolase) is an important enzyme that speeds up the hydrolysis of (alpha1,4) glycosidic linkage of carbohydrate and starch present in the diet and helps in absorption of non-absorbable polysaccharides after their conversion into absorbable monosaccharide (Alagesan et al. 2012). Inhibitors of amylase minimize the hydrolysis of (alpha-1,4) glycosidic linkage and help in slow digestion of carbohydrate and thus delay the absorption of glucose and reduces the postprandial glucose level in blood (Jayaraj et al. 2013).

The Pinto beans are a rich source of proteins and other nutrients but are not well explored for its therapeutic benefits. Pinto bean protein fraction was digested enzymatically using protease (Protamex) at $\mathrm{pH} 6.5$, and for the incubation period of 1-h with (E/S) ratio of $1: 10$ at $50{ }^{\circ} \mathrm{C}$, hydrolysed fraction was dialysed using molecular weight cutoffs and the fraction obtained with molecular weight $<3 \mathrm{kDa}$ showed $62.10 \pm 3.49 \%$ of enzyme inhibition (Ngoh and Gan 2016). Similarly digestion with Protease (Bromelain) and dialysis with Molecular weight cut-off $<1 \mathrm{kDa}$ showed $49.9 \pm 1.4 \%$ of enzyme inhibition (Oseguera-Toledo et al. 2015). The peptide obtained from Cuminum cyminum L. (Cumin) seeds, cumin seed peptide1 (CSP1) had shown $24.54 \%$ of alphaamylase inhibition (Siow and Gan, 2016). In vitro study of
Triticum aestivum L. (Wheat) albumin extract showed alphaamylase inhibition, wheat albumin restrained the peak of postprandial blood glucose levels in a dose-dependent manner. It showed the reduction in postprandial blood glucose by $31 \%, 47 \%$, and $50 \%$ after administering $0.25 \mathrm{~g}, 0.5 \mathrm{~g}$, and $1.0 \mathrm{~g}$ of wheat albumin respectively. In long-term administration study, $0.5 \mathrm{~g}$ of wheat albumin did not affect fasting blood glucose levels, while it reduces hemoglobin A1c levels which reflects the metabolic control of individual suffering from diabetes (Kodama et al. 2005).

A study revealed that different protein fractions isolated from the Hordeum vulgare L. (Barley) flour have been subjected to pancreatic hydrolysis and the obtained peptides have shown $57-77 \%$ alpha-amylase inhibitory activity (Alu'datt et al. 2012). Cucurbitin protein was obtained from the Cucurbita pepo L. (Pumpkin) seeds, alcalase and pepsin hydrolysed fraction of it showed the enzyme inhibition (Vaštag et al. 2014). Oligopeptides from the Mulberry showed highest enzyme inhibition with $\mathrm{IC}_{50} 16.25 \mu \mathrm{g} / \mathrm{ml}$. Protein hydrolysates prepared from the seeds of Moringa oleifera Lam. by enzymes like trypsin, chymotrypsin and pepsin-trypsin for 2.5 and $5 \mathrm{~h}$. Pepsin-trypsin digested fraction showed alpha-amylase inhibition and the $\mathrm{IC}_{50}$ was found to be 0.195 and $0.123 \mu \mathrm{g} / \mathrm{ml}$ for $2.5 \mathrm{~h}$ and $5 \mathrm{~h}$ of hydrolysis respectively (Gonzalez Garza et al. 2017). Protein hydrolysate of Citrullus lanatus L. (Watermelon) seeds was prepared by using enzymes like pepsin, trypsin and alcalase where alcalase hydrolysate gives the highest enzyme inhibition and the $\mathrm{IC}_{50}$ was found to be $0.149 \mathrm{mg} / \mathrm{ml}$ (Arise 2016). Autolysates of Theobroma cacao L. fruits were prepared at $\mathrm{pH} 3.5$ and 5.2. Autolysate at $\mathrm{pH} 3.5$ showed highest inhibition of alpha-amylase as well as helps to release the insulin, in vivo study with autolysates showed decrease in the blood glucose level (Sarmadi et al. 2012). Quinoa proteins were enzymatically hydrolyzed to obtain bioactive peptides, hydrolyzed fraction thus obtained showed $6.86 \%$ inhibition of alpha-amylase at $250 \mu \mathrm{M}$ concentration (Vilcacundo et al. 2017).

\section{DipeptidyI Peptidase-IV Inhibitors}

Two main gut-derived hormones GLP-1 and glucosedependent insulinotropic polypeptide (GIP), also known incretin hormones are responsible for the attainment of normoglycemia. They stimulate insulin secretion, decrease glucagon, inhibit gastric emptying, reduce food intake and appetite (Drucker and Nauck 2006). In diabetic individuals, reduced secretion of incretin hormones have been observed. These gut hormones bind with their respective receptors and show their biological action (Barnett 2006). Treatment of diabetes requires to restore either normal secretion or reduce the degradation of these hormones. Dipeptidyl peptidaseIV (DPP-IV) is a protease enzyme that cleave the GLP-1 
hormone within minutes after its secretion and makes it inactive for biological function. Thus, inhibition of DPPIV has the potential to revert the hyperglycaemic condition. DPP-IV inhibitors block the rapid degradation of GLP-1 and enhance the postprandial level of active GLP-1 which further reduces the liver glucagon production and stimulate beta cells of the pancreas and increase insulin level (Ahrén 2007).

Dipeptides obtained from Oryza sativa L. (rice) bran protein hydrolysates showed inhibition of DPP-IV enzyme and have $\mathrm{IC}_{50} 1.45 \pm 0.13 \mathrm{mg} / \mathrm{ml}$ (Hatanaka et al. 2015). In another study, rice bran protein fractions have been defatted and hydrolyzed with umamizyme $\mathrm{G}$ and Bioprase SP. The dipeptides obtained after digestion with Umamizyme $\mathrm{G}$ showed inhibition of enzyme and the $\mathrm{IC}_{50}$ was found to be $2.3 \pm 0.1 \mathrm{mg} / \mathrm{ml}$ (Hatanaka et al. 2012). The proteins extracted from Amaranthus hypochondriacus L., have been subjected to simulated gastrointestinal digestion resulted into bioactive peptides. These peptides fraction have shown dose-dependent enzyme inhibition and have $\mathrm{IC}_{50} 1.1 \mathrm{mg} / \mathrm{ml}$ (Velarde-Salcedo et al. 2013). Glycine max L. (Soybean) and Lupinus albus L. (Lupin) protein hydrolysate have been screened for the presence of bioactive peptides, and Soy 1 and Lup 1 were found to be efficient inhibitors of DPP-IV with $\mathrm{IC}_{50}$ values 106 and $228 \mu \mathrm{M}$ respectively (Lammi et al. 2016). Peptides obtained (CPGNK and GGGLHK) from the protein digestion of common beans showed enzyme inhibitory activity and the $\mathrm{IC}_{50}\left(\mathrm{mg} \mathrm{DW} \mathrm{ml}^{-1}\right)$ for the pure peptides were found to be $0.87 \pm 0.02$ and $0.61 \pm 0.10$ respectively (Mojica et al. 2017b). Gastrointestinal digestion of proteins obtained from Phalaris canariensis L. (Canary) seed showed $43.5 \%$ inhibition of DPP-IV (Estrada-Salas et al. 2014). Enzymatic digestion of Quinoa proteins with papain showed enzyme inhibition and the $\mathrm{IC}_{50}$ for the hydrolysate-papain was found to be $0.88 \pm 0.05 \mathrm{mg} / \mathrm{ml}$ (Nongonierma et al. 2015). Study was performed on quinoa protein simulated duodenal digestion and the fraction ( $5 \mathrm{kDa}$ ) obtained after 120 min of digestion showed highest DPP-IV inhibition and the $\mathrm{IC}_{50}(\mathrm{mg}$ protein $/ \mathrm{mL})$ was found to be $0.84 \pm 0.07$ (Vilcacundo et al. 2017).

\section{Inhibitors of the Glucose Transporter System (GLUT and SGLT)}

Glucose, the metabolic fuel of any living cell, unable to cross lipid bilayer of the membrane due to its polar nature and membrane proteins (glucose transporter) associate with lipid bilayer helps glucose to travel across (Abdul-Ghani et al. 2011). GLUT transporters facilitate the transport of glucose passively across the membrane along with its concentration gradient and do not require energy to operate, on the other hand SGLT transporters actively transport glucose across the membrane against the concentration gradient thus these types of transporters require energy to operate. In order to receive energy for operation, sodium is transported along with its concentration or electrochemical gradient thus provide the needed amount of energy for the transportation of glucose across the membrane (Musso et al. 2012; Brown 2000). In the human body, at least 12 different GLUT transporters and 7 SGLT transporters exist which belongs to membrane class of proteins. Excreted glucose is reabsorbed up to $90 \%$ in a convoluted segment of proximal tubule via high capacity, low-affinity SGLT 2 transporter while remaining $10 \%$ of glucose is reabsorbed in the distal segment of proximal tubule via high affinity, low capacity SGLT 1 transporter.

In the case of diabetes, hyperglycemia causes the high load of glucose in order to compensate for this high load of glucose, an increase in expression of a glucose transporter gene in proximal tubule occurs (Abdul-Ghani et al. 2011). Plant peptides targeting glucose transporters are less explored. However, peptides having amino acid sequences AKSPLF, ATNPLF, FEELN, and LSVSVL, isolated from the black beans have shown the ability to block the glucose transporters GLUT-2 and SGLT-1. The results of in vitro studies by using the Caco- 2 cell model have shown reduced glucose re-absorption by $21.5 \%$ after $24 \mathrm{~h}$ treatment of these bioactive peptides. The oral glucose tolerance test in rats has shown a $24.5 \%$ decrease in postprandial glucose $(\mathrm{p}<0.05)$ (50 mg hydrolyzed protein isolate/kg BW) (Mojica et al. 2017a).

\section{Insulin Mimetics}

Insulin hormone trigger several signaling events that control the metabolic fate of nutrients. Insulin binds with alphasubunit of insulin receptor which causes the conformational changes in $\beta$-subunit of the insulin receptor, and these conformational changes in receptor activate the cytoplasmic tyrosine kinase domain. This activation further leads to the auto-phosphorylation which in turn trans-phosphorylate various intracellular substrate of the insulin receptor. These effects collectively control metabolic and mitogenic processes (Nankar and Doble, 2013). Tyrosine kinase domain activation by insulin mimetic, cause the auto-phosphorylation of receptor and trigger downstream signaling requires for metabolic activity of insulin. The other mechanism by which insulin mimetic (vanadate) works is by inhibiting the dephosphorylation of the insulin receptor via inhibition of tyrosine phosphatase (Stapleton 2000).

The reports suggest that plant extracts of spinach and Lemna gibba G-3 mimics like mammalian-insulin, which was confirmed by the radioimmunoassay. In an in vivo study on young rats indicated that the plant insulin-like material binds to insulin receptors on IM-9 lymphocytes and stimulates glucose oxidation and lipogenesis in isolated adipocytes (Collier et al. 1987). Vigna unguiculate L. (Cowpea) 
containing bio-molecules have contributed in reducing the blood glucose level and enhancing the antioxidant status of patients. Study on L6 rat skeletal muscle cells was performed where cells were treated with cowpea peptides at different doses $(0.1,1,10$ and $100 \mathrm{ng})$ for $20 \mathrm{~h}$ or insulin $(100 \mathrm{nM})$ for $30 \mathrm{~min}$. Further, from the treated cells proteins were isolated for western blot analysis to check the phosphorylation of Akt (a form of protein kinase B; PKB). The results of the study showed that the cowpea peptides have the ability to phosphorylated Akt in the cell culture. This observation suggests that the treatment of cowpea peptides to the skeletal muscle cells can initiate the insulin signaling cascade. There is a possibility that cowpea peptides have the ability to mimic like insulin by inducing the same signaling cascade (Uruakp, 2015).

Linum usitatissimum L. (Flax) seed peptides obtained from the protein hydrolysate $(50 \mathrm{kD})$ increases glucose uptake in L6 cells (Doyen et al. 2014). MC2-1-5 peptide fraction was obtained from Momordica charantia L. showed hypoglycaemic effect in in vivo study. MC2-1-5 fraction decreases the blood glucose level by $61.70 \%$ and $69.18 \%$ in alloxan-induced diabetic mice with a time interval of 2 and $4 \mathrm{~h}$ respectively (Yuan et al. 2008). Study on protein from the pulp of $M$. charantia $\mathrm{L}$. showed increase glucose uptake in $\mathrm{C} 2 \mathrm{C} 12$ myocytes and 3T3L adipocyte, the in vivo studies showed that the protein obtained from pulp helps in secretion of the insulin as well as act like insulin to lower the glucose level (Yibchok-Anun et al. 2006). Polypeptide-P was isolated from the $M$. charantia $\mathrm{L}$. acts like insulin mimetic (Khanna et al. 1981). Another 68-residue insulin receptor (IR)-binding protein (mcIRBP) was reported from the plant upon in vitro digestion yields mcIRBP-19, spanning residues 50-68 of mcIRBP which increases the binding of insulin to its receptor, stimulate the phosphorylation of PDK1 and Akt, induces the expression of glucose transporter 4 , and stimulate both the uptake of glucose in cells and the clearance of glucose in diabetic mice (Lo et al. 2016). A novel protein called MCy having molecular weight $17 \mathrm{kD}$ was isolated from Momordica cymbalaria L. fruit which showed hypoglycemic effect in in vivo study (Rajasekhar et al. 2010). The peptide fraction obtained from the soybean showed increase in glucose uptake in muscular cells, it is reported that obtained peptide fraction enhances the glucose uptake via AMK activation (Roblet et al. 2014).

Protein extract of Cucurbitaceae family containing seeds like Telfairia occidentalis Hook.f., Citrullus lanatus L., Lagenaria siceraria Molina., and Cucurbita moschata Duchesne., showed a significant decrease in blood sugar level in in vivo study (Teugwa et al. 2013). Peptide reported from the leaves of Bauhinia variegata $\mathrm{L}$, mimics like insulin which is evidently proved from the immunological reactivity and via in vivo study (Azevedo et al. 2006). Zea mays L. (Zein) seed protein hydrolysate increase the secretion of GLP-1 directly in the ileum and indirectly in the duodenum in the rat and also confirmed with the help of GLUTag cell line study (Hira et al. 2009). Aglycine which is a bioactive peptide obtained from the soy bean increases the glucose uptake in $\mathrm{C} 2 \mathrm{C} 12$ cell, whereas in in vivo study on diabetic model it was observed that treatment with aglycine increases the expression of p-IR, p-IRS1, p-Akt and membrane GLUT4 protein which results into hypoglycemia (Lu et al. 2012). Soymorphin- 5 also called $\mu$-opioid obtained from soy bean decreases the blood glucose level via activation of adiponectin and PPAR $\alpha$ systems in diabetic KKAy mice (Yamada et al. 2011). Rice bran protein hydrolysate helps to improve insulin resistance and prevent metabolic diseases (Boonloh et al. 2015). Protein extracted from the fruit pulp of Momordica dioica Roxb. decreases the blood glucose level in a diabetic model (Poovitha et al. 2017). Plant scientist believe that there are more plants left unexplored which may contain insulin-like peptides or peptides which will mimic insulin (Xavier-Filho et al. 2003).

\section{Challenges Associated with Peptides as a Drug}

The success of any therapy and its acceptability depends on the ease of its delivery. The oral route of drug administration remains the most accepted route of drug delivery and most of the available drugs in the market are delivered through the oral route (Morishita and Peppas 2006). An orally active drug should be stable enough to withstand the gastric microenvironment and also it should be permeable through the gastrointestinal membrane. Small molecules are well tolerant to the gastric $\mathrm{pH}$ and permeated through the membrane whereas the large macromolecules are vulnerable to degradation in the gastrointestinal tract and are not permeable in their intact form to reach specific target successfully without being degraded in GIT (Morishita and Peppas 2006). As the medical field advances, the peptide drugs are widely explored for their therapeutic potential in the treatment of various diseases. Though these drugs are specific to their target, efficacious and potent, the oral bioavailability of peptide and peptide-based drugs always remains a challenge that limits their wide acceptance and market value. High cost of therapy is a major limitation associated with peptide drugs (Ayoub and Scheidegger 2006). With the advancement of biotechnology, the recombinant synthesis of a peptide of interest opens a door for cheap and cost-effective peptides. Also, the commercial interest for the production of bioactive peptides from the natural sources is elevated to reduce the cost but due to the lack of suitable technologies which helps to retain or increase the activity of bioactive peptides, the large-scale production gets hampered (Craik et al. 2013).

Another limitation associated with peptide-based drugs is their short half-life. When the peptides come in contact with intestinal mucosa, gastric acid in stomach and 
peptidases that are present in the blood convert peptides into amino acids and gets quickly eliminated from the body, thereby reducing its half-life. In order to achieve prolonged action and to reduce the frequent dosing, it is necessary to increase the half-life of the peptides. As peptide therapeutics advances, several non-degradable polymers and polymeric matrix are available to increase the half-life of peptides and proteins thus reducing the frequent dosing (Brown 2005). Another strategy to increase the half-life of the peptide is to modify the amino acids which are susceptible to cleavage by enzymes (Adessi and Soto 2002). Oral delivery of the peptides is explored in past years but limits its use as peptides are degraded in the GIT tract (Lau et al. 2015). Novo Nordisk developed a semaglutide oral formulation which is currently in clinical trial phase 3. Other non-invasive and suitable routes for the peptide and protein-based drugs are under investigation includes the nasal and pulmonary route which directly deliver the drugs to the blood component hence, reduces the overall drug degradation which is the main drawback associated with oral delivery of peptides (Davies et al. 2017).

\section{Future of Peptide-Based Drugs}

Different therapeutic peptides have made their way to the market in recent years, and it is assumed that the market demand will increase further as peptides are specific, selective and safe in comparison to small molecules (Fosgerau and Hoffmann 2015; Loffet 2002). Traditional synthesis and drug design approaches are used by researchers and pharmaceutical companies for the development of the peptide-based drug candidate. The recombinant protein is another tool for the synthesis of the desired peptide in bacteria, yeast, and fungi. The market of peptides has now moved from the isolation of peptides from an animal source that can mimic the endogenous peptide to synthetic, semi-synthetic and recombinant peptides. Further, development in this area is drug conjugated peptides and multifunctional peptides (Fosgerau and Hoffmann 2015). Peptides are susceptible to degradation when given orally, which is supposed to be the most convenient route of administration. The preferred route for the peptide delivery is intravenous, however, more research is directed for the delivery of peptides. Recently, alternative routes are explored, which include oral, transdermal and intranasal route. As peptides are excellent biomarkers, they can also be utilized for diagnosing diseases. Further, peptides are also found to be advantageous in vaccine development (Brown 2005; Sheridan 2012).

Plant peptides have been isolated and characterized in different ways as described in Fig. 3. X-ray crystallography and NMR have contributed enormously in the field of structure elucidation of pure peptides (Gomathi and Subramanian
Fig. 3 The general scheme of isolation, purification, and characterization of plant peptides (Gomathi and Subramanian 1996; Krishnan and Rupp 2012; Sinz et al. 2015; Wysocki et al. 2005)

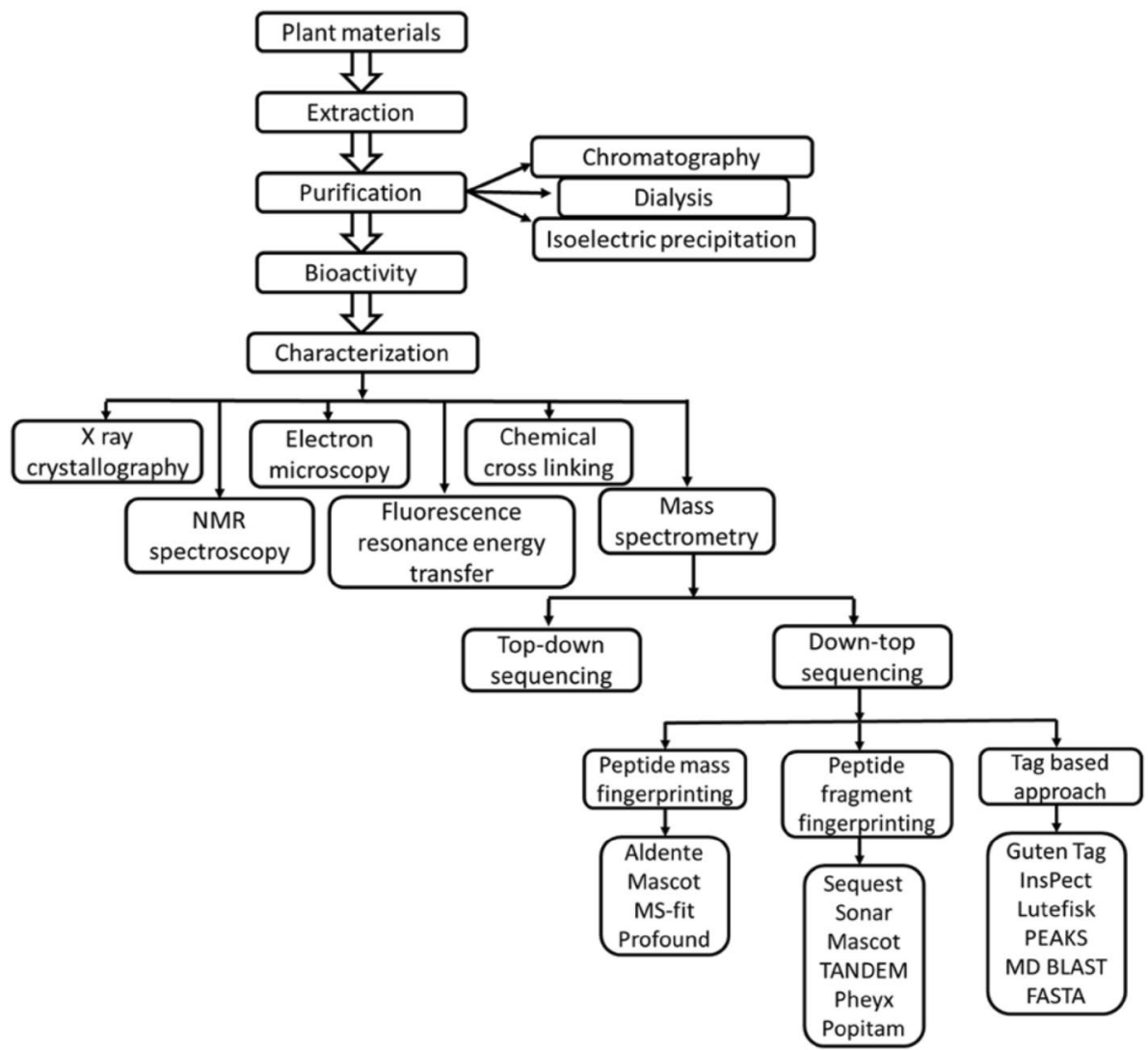


1996; Krishnan and Rupp 2012). Other techniques like electron microscopy, fluorescence resonance energy transfer, chemical cross-linking emerged in recent year for the characterization of proteins and peptides (Sinz et al. 2015). Mass spectrometry is frequently used technique in analyzing peptide mixtures and identifying their proposed structures. Amino acid sequencing in mass spectrometry can be performed by two methods namely top-down sequencing and down-top sequencing. In top-down sequencing, the proteins analysis is performed without hydrolysis and the molecular weight can be detected by fragmentation pattern of the whole protein. A common approach is down-top sequencing in which proteolytic digestion is performed followed by MS analysis. Software based on the algorithm of the amino acid sequence is available for protein identification (Wysocki et al. 2005).

\section{Discussion}

Plants remain a valuable source for developing a new drug candidate. They are still sharing their fair share of the new drug candidates and lead. As research interest is now shifted from small molecules to bio-molecules by virtue of several added benefits, plants are now under exploration for the presence of proteins and bioactive peptides for the disease management. Though plant proteins and their functions have not been defined earlier, plant hormones were only considered through which cells communicate, as our understanding to these signalling pathways become clear, several secreted peptides and small RNAs now known which regulates molecular recognition and thus, controls cell communication. From our diet we consume proteins which after gastrointestinal digestion get converted to bioactive peptides with more tissue affinity to specific receptor. Several research publications in recent years claimed plant proteins and their bioactive peptides as a potential candidate in the treatment of various diseases specially in metabolic and life style borne diseases including cancer, diabetes and obesity. Sophisticated instrument and advancement in technology leads easy isolation, purification and characterization of proteins and peptides in a short period of time, which further reduces the overall time of discovery.

Apparently, most of the bioactive peptides available for the treatment of diabetes have emerged from the synthetic route or derived from recombinant technology, which further adds in the overall cost of the treatment. To make peptide therapy economic there is a demand to explore plant-based biomolecules. This review discusses bioactive peptide isolated from various plant parts like leaves, fruits and seeds. The trend indicates that most of the bioactive peptides are obtained from seeds, although reports are available where bioactive peptides have been also isolated from leaves, whole fruits and pulps.
It was observed in various in vitro and in vivo studies that protein hydrolysate obtained from aqueous extracts of plant are capable of inhibiting the enzymes and transporter systems responsible for the diabetes. Expedition to find molecular targets and mechanism of action of plant based bioactive peptides is needed to use these bioactive peptides as a potential drug candidate.

\section{Conclusion}

Epidemiological data reveals that type 2 diabetes requires promising therapy as the available synthetic drugs for the treatment have moderate to severe adverse effects. Plant-derived bioactive peptides inhibit the enzymes like alpha-glucosidase, alpha-amylase, dipeptidyl peptidase-IV and glucose transporter systems involved in type 2 diabetes. In vivo studies of a certain plant peptides fraction showed insulin-mimetic action in animal models. It is clear that plant-derived bioactive peptides are not explored to their full potential in comparison to other classes of natural products. The reason might be the lack of suitable instrumental techniques to identify, purify and characterize the peptides from plant source. However, the recent advancement in LCMS, LC-NMR, and X-ray crystallography has bridged the gap and this would be the right time to embark on plant peptides. In future, systematic studies including dereplication for the early identification of known peptides, target identification followed by in vivo studies would help to speed up the plant peptides research.

Acknowledgements The authors want to thank NIPER Ahmedabad, under the aegis of the Ministry of Chemicals and Fertilizers, Department of Pharmaceuticals for providing facilities and research fellowships.

Author Contributions All the authors prepared, revised and edited the manuscript.

Funding Funding was received from NIPER Ahmedabad, under the aegis of the Ministry of Chemicals and Fertilizers, Department of Pharmaceuticals in terms of providing facilities and research fellowship.

\section{Compliance with Ethical Standards}

Conflict of interest The authors declare there is no conflict of interest.

Ethical Approval This article does not contain any studies with human participants or animals performed by any of the authors.

\section{References}

Abdul-Ghani MA, Norton L, Defronzo RA (2011) Role of sodiumglucose cotransporter 2 (SGLT 2) inhibitors in the treatment of type 2 diabetes. Endocr Rev 32:515-531

Adessi C, Soto C (2002) Converting a peptide into a drug: strategies to improve stability and bioavailability. Curr Med Chem 9:963-978 
Ahrén B (2007) Dipeptidyl peptidase-4 inhibitors: clinical data and clinical implications. Diabetes Care 30:1344-1350

Alagesan K, Raghupathi PK, Sankarnarayanan S (2012) Amylase inhibitors: potential source of anti-diabetic drug discovery from medicinal plants. Int J Pharm Life Sci 3:1407-1412

Alu'datt MH, Ereifej K, Abu-Zaiton A, Alrababah M, Almajwal A, Rababah T, Yang W (2012) Anti-oxidant, anti-diabetic, and anti-hypertensive effects of extracted phenolics and hydrolyzed peptides from barley protein fractions. Int J Food Prop 15:781-795

Aramadhaka LR, Prorock A, Dragulev B, Bao Y, Fox JW (2013) Connectivity maps for biosimilar drug discovery in venoms: the case of Gila monster venom and the anti-diabetes drug Byetta ${ }^{\circledR}$. Toxicon 69:160-167

Arise RO (2016) In vitro antioxidant and $\alpha$-amylase inhibitory properties of watermelon seed protein hydrolysates. Environ Exp Biol 14:163-172

Ayoub M, Scheidegger D (2006) Peptide drugs, overcoming the challenges, a growing business. Chim Oggi 24:46

Azevedo CR, Maciel FM, Silva LB, Ferreira ATS, Da Cunha M, Machado OLT, Fernandes KVS, Oliveira AEA, Xavier-Filho $\mathrm{J}$ (2006) Isolation and intracellular localization of insulin-like proteins from leaves of Bauhinia variegata. Braz J Med Biol Res 39: $1435-1444$

Barnett A (2006) DPP-4 inhibitors and their potential role in the management of type 2 diabetes. Int J Clin Pract 60:1454-1470

Baynes H (2015) Classification, pathophysiology, diagnosis and management of diabetes mellitus. J Diabetes Metab 6:1-9

Boonloh K, Kukongviriyapan V, Kongyingyoes B, Kukongviriyapan U, Thawornchinsombut S, Pannangpetch P (2015) Rice bran protein hydrolysates improve insulin resistance and decrease pro-inflammatory cytokine gene expression in rats fed a high carbohydrate-high fat diet. Nutrients 7:6313-6329

Brito VN, Latronico AC, Arnhold IJ, Mendonca BB (2004) A single luteinizing hormone determination 2 hours after depot leuprolide is useful for therapy monitoring of gonadotropin-dependent precocious puberty in girls. J Clin Endocrinol Metab 89:4338-4342

Brown G (2000) Glucose transporters: structure, function and consequences of deficiency. J Inherit Metab Dis 23:237-246

Brown LR (2005) Commercial challenges of protein drug delivery. Expert Opin Drug Deliv 2:29-42

Ceriello A, Hanefeld M, Leiter L, Monnier L, Moses A, Owens D, Tajima N, Tuomilehto J (2004) Postprandial glucose regulation and diabetic complications. Arch Intern Med 164:2090-2095

Coherent market insights (2016). Available at https://www.coherentma rketinsights.com/market-insight/peptide-therapeutics-marke t-1837. Accessed July 2019

Collier E, Watkinson A, Cleland CF, Roth J (1987) Partial purification and characterization of an insulin-like material from spinach and Lemna gibba G3. J Biol Chem 262:6238-6247

Craik DJ, Fairlie DP, Liras S, Price D (2013) The future of peptidebased drugs. Chem Biol Drug Des 81:136-147

Creighton TE (1993) Proteins: structures and molecular properties. Macmillan, New York

Daliri EB, Oh DH, Lee BH (2017) Bioact Pept Foods 6(5):32

Davies M, Pieber TR, Hartoft-Nielsen M-L, Hansen OK, Jabbour S, Rosenstock J (2017) Effect of oral semaglutide compared with placebo and subcutaneous semaglutide on glycemic control in patients with type 2 diabetes: a randomized clinical trial. JAMA 318:1460-1470

Deepthi B, Sowjanya K, Lidiya B, Bhargavi R, Babu P (2017) A modern review of diabetes mellitus: an annihilatory metabolic disorder. J In Silico In Vitro Pharmacol 3:14

Dezzani L (2017) Bloomberg markets top 20 diabetes drugs 2017. https ://diabetestalk.net/paging/insulin/insulin-sales-2016/. Accessed July 2019
Doyen A, Udenigwe CC, Mitchell PL, Marette A, Aluko RE, Bazinet L (2014) Anti-diabetic and antihypertensive activities of two flaxseed protein hydrolysate fractions revealed following their simultaneous separation by electrodialysis with ultrafiltration membranes. Food Chem 145:66-76

Drucker DJ, Nauck MA (2006) The incretin system: glucagon-like peptide- 1 receptor agonists and dipeptidyl peptidase- 4 inhibitors in type 2 diabetes. Lancet 368:1696-1705

Duda PW, Schmied MC, Cook SL, Krieger JI, Hafler DA (2000) Glatiramer acetate (Copaxone $\left.{ }^{\circledR}\right)$ induces degenerate, Th2polarized immune responses in patients with multiple sclerosis. J Clin Investig 105:967-976

Edmonds DJ, Price DA (2013) Oral GLP-1 modulators for the treatment of diabetes. In: Edmonds DJ, Price DA (eds) Annual reports in medicinal chemistry. Elsevier, Amsterdam

Estrada-Salas PA, Montero-Moran GM, Martinez-Cuevas PP, Gonzalez C, Barba de la Rosa AP (2014) Characterization of antidiabetic and antihypertensive properties of canary seed (Phalaris canariensis L.) peptides. J Agric Food Chem 62:427-433

Fosgerau K, Hoffmann T (2015) Peptide therapeutics: current status and future directions. Drug Discov Today 20:122-128

Fukushima M, Watanabe S, Kushima K (1976) Extraction and purification of a substance with luteinizing hormone releasing activity from the leaves of Avena sativa. Tohoku J Exp Med 119:115-122

Gautam N (1999) Defects in signal transduction proteins leading to disease. In: Sitaramayya A (ed) Introduction to cellular signal transduction. Springer, Boston

Ghorbani S (2014) Signaling peptides in plants. Cell Dev Biol. https ://doi.org/10.4172/2168-9296.1000141

Gomathi L, Subramanian S (1996) Elucidation of secondary structures of peptides using high resolution NMR. Curr Sci 71:553-567

Gonzalez Garza NG, Chuc Koyoc JA, Torres Castillo JA, Garcia Zambrano EA, Betancur Ancona D, Chel Guerrero L, Sinagawa Garcia SR (2017) Biofunctional properties of bioactive peptide fractions from protein isolates of moringa seed (Moringa oleifera). J Food Sci Technol 54:4268-4276

Gueguen J, Cerletti P (1994) Proteins of some legume seeds: soybean, pea, fababean and lupin. In: Hudson BJF (ed) New and developing sources of food proteins. Springer, Boston

Hartmann R, Meisel H (2007) Food-derived peptides with biological activity: from research to food applications. Curr Opin Biotechnol 18:163-169

Hatanaka T, Inoue Y, Arima J, Kumagai Y, Usuki H, Kawakami K, Kimura M, Mukaihara T (2012) Production of dipeptidyl peptidase IV inhibitory peptides from defatted rice bran. Food Chem 134:797-802

Hatanaka T, Uraji M, Fujita A, Kawakami K (2015) Anti-oxidation activities of rice-derived peptides and their inhibitory effects on dipeptidylpeptidase-IV. Int J Pept Res Ther 21:479-485

Henninot A, Collins JC, Nuss JM (2018) The current state of peptide drug discovery: back to the future? J Med Chem 61:1382-1414

Hira T, Mochida T, Miyashita K, Hara H (2009) GLP-1 secretion is enhanced directly in the ileum but indirectly in the duodenum by a newly identified potent stimulator, zein hydrolysate, in rats. Am J Physiol Gastrointest Liver Physiol 297:663-671

Jayaraj S, Suresh S, Kadeppagari RK (2013) Amylase inhibitors and their biomedical applications. Starch-Stärke 65:535-542

Jha S, Gupta SK, Bhattacharyya P, Ghosh A, Mandal P (2018) In vitro antioxidant and antidiabetic activity of oligopeptides derived from different mulberry (Morus alba L.) cultivars. Pharmacogn Res 10:361

Khanna P, Jain SC, Panagariya A, Dixit VP (1981) Hypoglycemic activity of polypeptide-p from a plant source. J Nat Prod $44: 648-655$ 
Kitts DD, Weiler K (2003) Bioactive proteins and peptides from food sources. Applications of bioprocesses used in isolation and recovery. Curr Pharm Des 9:1309-1323

Kodama T, Miyazaki T, Kitamura I, Suzuki Y, Namba Y, Sakurai J, Torikai Y, Inoue S (2005) Effects of single and long-term administration of wheat albumin on blood glucose control: randomized controlled clinical trials. Eur J Clin Nutr 59:384-392

Krishnan V, Rupp B (2012) Macromolecular structure determination: comparison of X-ray crystallography and NMR spectroscopy. eLS. https://doi.org/10.1002/9780470015902.a0002716.pub2

Lammi C, Zanoni C, Arnoldi A, Vistoli G (2016) Peptides derived from soy and lupin protein as dipeptidyl-peptidase IV inhibitors: in vitro biochemical screening and in silico molecular modeling study. J Agric Food Chem 64:9601-9606

Lau J, Bloch P, Schaffer L, Pettersson I, Spetzler J, Kofoed J, Madsen K, Knudsen LB, Mcguire J, Steensgaard DB, Strauss HM, Gram DX, Knudsen SM, Nielsen FS, Thygesen P, Reedtz-Runge S, Kruse T (2015) Discovery of the once-weekly glucagonlike peptide-1 (GLP-1) analogue semaglutide. J Med Chem 58:7370-7380

Leroith D, Pickens W, Wilson GL, Miller B, Berelowitz M, Vinik AI, Collier E, Cleland CF (1985) Somatostatin-like material is present in flowering plants. Endocrinology 117:2093-2097

Li Y, Yu J (2015) Research progress in structure-activity relationship of bioactive peptides. J Med Food 18:147-156

Lindsey K, Casson S, Chilley P (2002) Peptides: new signalling molecules in plants. Trends Plant Sci 7:78-83

Lo HY, Li CC, Ho TY, Hsiang CY (2016) Identification of the bioactive and consensus peptide motif from Momordica charantia insulin receptor-binding protein. Food Chem 204:298-305

Loffet A (2002) Peptides as drugs: is there a market? J Pept Sci 8:1-7

Loganathan V (2016) Growth potential in peptide and protein therapeutics to enhance supplier capacities [Online]. https://www.beroe inc.com/whitepaper/peptides-proteins/. Accessed 19 Oct 2018

Lu J, Zeng Y, Hou W, Zhang S, Li L, Luo X, Xi W, Chen Z, Xiang M (2012) The soybean peptide aglycin regulates glucose homeostasis in type 2 diabetic mice via IR/IRS1 pathway. J Nutr Biochem 23:1449-1457

Lund A, Knop FK, Vilsbøll T (2014) Glucagon-like peptide-1 receptor agonists for the treatment of type 2 diabetes: differences and similarities. Eur J Intern Med 25:407-414

Magon N (2011) Gonadotropin releasing hormone agonists: expanding vistas. Indian J Endocrinol Metab 15:261

Marella S, Maddirela DR, Kumar EG, Tilak TK, Badri KR, Chippada A (2016) Mcy protein, a potential antidiabetic agent: evaluation of carbohydrate metabolic enzymes and antioxidant status. Int $\mathbf{J}$ Biol Macromol 86:481-488

Mojica L, De Mejía EG (2016) Optimization of enzymatic production of anti-diabetic peptides from black bean (Phaseolus vulgaris L.) proteins, their characterization and biological potential. Food Funct 7:713-727

Mojica L, Gonzalez de Mejia E, Granados-Silvestre MÁ, Menjivar M (2017a) Evaluation of the hypoglycemic potential of a black bean hydrolyzed protein isolate and its pure peptides using in silico, in vitro and in vivo approaches. J Funct Foods 31:274-286

Mojica L, Luna-Vital DA, Gonzalez de Mejia E (2017b) Characterization of peptides from common bean protein isolates and their potential to inhibit markers of type- 2 diabetes, hypertension and oxidative stress. J Sci Food Agric 97:2401-2410

Moller NP, Scholz-Ahrens KE, Roos N, Schrezenmeir J (2008) Bioactive peptides and proteins from foods: indication for health effects. Eur J Nutr 47:171-182

Mooradian AD, Thurman JE (1999) Drug therapy of postprandial hyperglycaemia. Drugs 57:19-29

Morishita M, Peppas NA (2006) Is the oral route possible for peptide and protein drug delivery? Drug Discov Today 11:905-910
Morley JE, Meyer N, Pekary AE, Melmed S, Carlson HE, Briggs JE, Hershman JM (1980) A prolactin inhibitory factor with immunocharacteristics similar to thyrotropin releasing factor (TRH) is present in rat pituitary tumors (GH3 and W5), testicular tissue and a plant material, alfalfa. Biochem Biophys Res Commun 96:47-53

Murphy E, Smith S, De Smet I (2012) Small signaling peptides in Arabidopsis development: how cells communicate over a short distance. Plant Cell 24:3198-3217

Musso G, Gambino R, Cassader M, Pagano G (2012) A novel approach to control hyperglycemia in type 2 diabetes: sodium glucose cotransport (SGLT) inhibitors: systematic review and meta-analysis of randomized trials. Ann Med 44:375-393

Nankar RP, Doble M (2013) Non-peptidyl insulin mimetics as a potential antidiabetic agent. Drug Discov Today 18:748-755

Nathan DM, Buse JB, Davidson MB, Ferrannini E, Holman RR, Sherwin R, Zinman B (2009) Medical management of hyperglycemia in type 2 diabetes: a consensus algorithm for the initiation and adjustment of therapy: a consensus statement of the American Diabetes Association and the European Association for the Study of Diabetes. Diabetes Care 32:193-203

Nehete JY, Bhambar RS, Narkhede MR, Gawali SR (2013) Natural proteins: sources, isolation, characterization and applications. Pharmacogn Rev 7:107-116

Ngoh YY, Gan CY (2016) Enzyme-assisted extraction and identification of antioxidative and alpha-amylase inhibitory peptides from Pinto beans (Phaseolus vulgaris cv. Pinto). Food Chem 190:331-337

Nongonierma AB, Le Maux S, Dubrulle C, Barre C, Fitzgerald RJ (2015) Quinoa (Chenopodium quinoa Willd.) protein hydrolysates with in vitro dipeptidyl peptidase IV (DPP-IV) inhibitory and antioxidant properties. J Cereal Sci 65:112-118

Oseguera-Toledo ME, Gonzalez de Mejia E, Amaya-Llano SL (2015) Hard-to-cook bean (Phaseolus vulgaris L.) proteins hydrolyzed by alcalase and bromelain produced bioactive peptide fractions that inhibit targets of type- 2 diabetes and oxidative stress. Food Res Int 76:839-851

Otvos L (2008) Peptide-based drug design: here and now. In: Otvos L (ed) Peptide-based drug design. Humana Press, Totowa

Otvos L Jr, Wade JD (2014) Current challenges in peptide-based drug discovery. Front Chem 2:62

Piero MN (2015) Diabetes mellitus—a devastating metabolic disorder. Asian J Biomed Pharm Sci 4:1-7

Poovitha S, Siva Sai M, Parani M (2017) Protein extract from the fruit pulp of Momordica dioica shows anti-diabetic, anti-lipidemic and antioxidant activity in diabetic rats. J Funct Foods 33:181-187

Quianzon CC, Cheikh I (2012) History of insulin. J Commun Hosp Intern Med Perspect 2:18701

Rajasekhar MD, Badri KR, Vinay Kumar K, Babu KR, Fatima SS, Sampath Kumar MT, Appa Rao C (2010) Isolation and characterization of a novel antihyperglycemic protein from the fruits of Momordica cymbalaria. J Ethnopharmacol 128:58-62

Ren Y, Liang K, Jin Y, Zhang M, Chen Y, Wu H, Lai F (2016) Identification and characterization of two novel $\alpha$-glucosidase inhibitory oligopeptides from hemp (Cannabis sativa L.) seed protein. J Funct Foods 26:439-450

Roblet C, Doyen A, Amiot J, Pilon G, Marette A, Bazinet L (2014) Enhancement of glucose uptake in muscular cell by soybean charged peptides isolated by electrodialysis with ultrafiltration membranes (EDUF): activation of the AMPK pathway. Food Chem 147:124-130

Roglic G (2016) World Health Organization. Available at https://www. who.int/news-room/fact-sheets/detail/diabetes. Accessed July 2019

Roth J, Leroith D, Shiloach J, Rosenzweig JL, Lesniak MA, Havrankova J (1982) The evolutionary origins of hormones, 
neurotransmitters, and other extracellular chemical messengers: implications for mammalian biology. N Engl J Med 306:523-527

Salvatore T, Giugliano D (1996) Pharmacokinetic-pharmacodynamic relationships of Acarbose. Clin Pharmacokinet 30:94-106

Sarmadi B, Aminuddin F, Hamid M, Saari N, Abdul-Hamid A, Ismail A (2012) Hypoglycemic effects of cocoa (Theobroma cacao L.) autolysates. Food Chem 134:905-911

Scheen AJ (2003) Is there a role for $\alpha$-glucosidase inhibitors in the prevention of type 2 diabetes mellitus? Drugs 63:933-951

Sheridan C (2012) Proof of concept for next-generation nanoparticle drugs in humans. Nat Biotechnol 30(6):471-473

Sinz A, Arlt C, Chorev D, Sharon M (2015) Chemical cross-linking and native mass spectrometry: a fruitful combination for structural biology. Protein Sci 24:1193-1209

Siow H-L, Gan C-Y (2016) Extraction, identification, and structureactivity relationship of antioxidative and $\alpha$-amylase inhibitory peptides from cumin seeds (Cuminum cyminum). J Funct Foods 22:1-12

Stapleton S (2000) Selenium: an insulin mimetic. Cell Mol Life Sci CMLS 57:1874-1879

Teugwa CM, Boudjeko T, Tchinda BT, Mejiato PC, Zofou D (2013) Anti-hyperglycaemic globulins from selected Cucurbitaceae seeds used as antidiabetic medicinal plants in Africa. BMC Complement Altern Med 13:63

Uhlig T, Kyprianou T, Martinelli FG, Oppici CA, Heiligers D, Hills D, Calvo XR, Verhaert P (2014) The emergence of peptides in the pharmaceutical business: from exploration to exploitation. EuPA Open Proteom 4:58-69

Uruakp F (2015) Influence of Cowpea (Vigna unguiculata) peptides on insulin resistance. J Nutr Health Food Sci 3:1-3

Van Norman JM, Breakfield NW, Benfey PN (2011) Intercellular communication during plant development. Plant Cell 23:855-864

Vaštag Z, Popovic L, Popovic S (2014) Bioactivity evaluation of cucurbitin derived enzymatic hydrolysates. Proc S. Popovic 8:445-448

Velarde-Salcedo AJ, Barrera-Pacheco A, Lara-Gonzalez S, MonteroMoran GM, Diaz-Gois A, Gonzalez de Mejia E, Barba de la Rosa AP (2013) In vitro inhibition of dipeptidyl peptidase IV by peptides derived from the hydrolysis of amaranth (Amaranthus hypochondriacus L.) proteins. Food Chem 136:758-764

Verpoorte R (1998) Exploration of nature's chemodiversity: the role of secondary metabolites as leads in drug development. Drug Discov Today 3:232-238

Vilcacundo R, Martínez-Villaluenga C, Hernández-Ledesma B (2017) Release of dipeptidyl peptidase IV, $\alpha$-amylase and $\alpha$-glucosidase inhibitory peptides from quinoa (Chenopodium quinoa Willd.) during in vitro simulated gastrointestinal digestion. J Funct Foods 35:531-539

Vitetta L, Anton B, Cortizo F, Sali A (2005) Mind-body medicine: stress and its impact on overall health and longevity. Ann N Y Acad Sci 1057:492-505

Votey, S. R. \& Peters, A. 2005. Diabetes mellitus, type 2-a review. Retrieved December, 5, 2006

Wang J, Du K, Fang L, Liu C, Min W, Liu J (2018) Evaluation of the antidiabetic activity of hydrolyzed peptides derived from Juglans mandshurica Maxim fruits in insulin-resistant HepG2 cells and type 2 diabetic mice. J Food Biochem 42:e12518

Wysocki VH, Resing KA, Zhang Q, Cheng G (2005) Mass spectrometry of peptides and proteins. Methods 35:211-222

Xavier-Filho J, Oliveira AEA, Silva LBD, Azevedo CR, Venâncio TM, Machado OLT, Oliva ML, Fernandes KVS, Xavier-Neto J (2003) Plant insulin or glucokinin: a conflicting issue. Braz J Plant Physiol 15:67-78

Yamada Y, Muraki A, Oie M, Kanegawa N, Oda A, Sawashi Y, Kaneko K, Yoshikawa M, Goto T, Takahashi N (2011) Soymorphin-5, a soy-derived $\mu$-opioid peptide, decreases glucose and triglyceride levels through activating adiponectin and PPAR $\alpha$ systems in diabetic KKAy mice. Am J Physiol-Endocrinol Metab 302:E433-E440

Yao Y, Cheng X, Ren G (2014) Alpha-Glucosidase inhibitory activity of protein-rich extracts from extruded adzuki bean in diabetic KK-Ay mice. Food Funct 5:966-971

Yibchok-Anun S, Adisakwattana S, Yao CY, Sangvanich P, Roengsumran S, Hsu WH (2006) Slow acting protein extract from fruit pulp of Momordica charantia with insulin secretagogue and insulinomimetic activities. Biol Pharm Bull 29:1126-1131

Yuan X, Gu X, Tang J (2008) Purification and characterisation of a hypoglycemic peptide from Momordica Charantia L. Var. abbreviata Ser. Food Chem 111:415-420

Zhang H, Wang J, Liu Y, Sun B (2015) Peptides derived from oats improve insulin sensitivity. J Biomed Sci 4:1-7

Publisher's Note Springer Nature remains neutral with regard to jurisdictional claims in published maps and institutional affiliations.

\section{Affiliations}

\section{Shital P. Patil ${ }^{1} \cdot$ Ashutosh Goswami $^{1} \cdot$ Kiran Kalia $^{2} \cdot$ Abhijeet S. Kate $^{1}$ D}

1 Department of Natural Products, National Institute of Pharmaceutical Education and Research, Ahmedabad, Gujarat, India
2 Department of Biotechnology, National Institute of Pharmaceutical Education and Research, Ahmedabad, Gujarat, India 